\title{
Role of forest provisioning services to local livelihoods: based on relative forest income (RFI) approach in southwest Ethiopia coffee forest
}

\author{
Ayehu Fekadu ${ }^{{ }^{*}}\left(\mathbb{D}\right.$, Teshome Soromessa ${ }^{10}$ and Bikila Warkineh Dullo ${ }^{2}$ (D)
}

\begin{abstract}
Background: This study provides empirical evidence, for the contribution of forest provisioning ecosystem services to the local communities done on the Afromontum rainforest of southwest Ethiopia which is endowed with many Fauna and Flora. The study may give some representative evidence for policy-maker on behalf of conservation of the area.

Methodology: This study was done with the approach of focus group discussion and in-depth interviews of the rural community in southwest Ethiopia coffee forest. The role of forest provisioning services analysis was made by relative forest income (RFI) procedure based on the stratification category of the local ethnics and newcomers.

Results: The overall result indicated that seventeen forest provisioning services collected by the community from natural forest, however income were varied in relation to demographic features, the income from forest for local communities shown too high to which contributes $90.85 \%$ of the total income and have a long history of the link between this livelihood and forest. While forest also provides a considerable income for the new resettled community coming from elsewhere in the area but we observed non-forest income were the main source of revenue for this community.

Conclusions: The traditional and the indigenous communities used for access to a finite resource and considered the resource harvested from the forest are the central part of their economy and the relationships between forests and people's livelihoods particularly for this remote community were complementary. Then planning should take into conceder, in policy perceptive, for supporting this remote community for livelihood improvement and conservation of this natural forest.
\end{abstract}

Keywords: Forest, Provisioning services, Indigenous, Non-indigenous, RFI

\section{Background}

Rural households are dependent on wild natural resources to come across the needs of current consumption (Neumann and Hirsch 2000), and for saleable exploitation of forest products and other natural resources (Belcher and Schreckenberg 2007). The lens on forest provisioning service which interpreted the income, are

\footnotetext{
*Correspondence: Ayehufekadu5@gmail.com

${ }^{1}$ Center of Environmental Science, Addis Ababa University, P.O. Box 1176,

Addis Ababa, Ethiopia

Full list of author information is available at the end of the article
}

very different interpretations of the global assessments to the household level (McSweeney 2002). Forest areas also tend to be remote from markets, this influence forest use (Sunderlin et al. 2005). However, the role of remoteness in forest conservation has been well observed today (Angelsen 2007) that, more likely to be preserved and less valued (Angelsen and Wunder 2003). The forest reliance on remote areas is more common, to be economically marginalized since few wage jobs, and subsistence-based livelihoods traditions (Sunderlin et al. 2005). Forest benefits, that provide to humans is considerable products and 
services constitute values that people derive from forests (Sasaki and Putz 2009). Harvesting of forest products, is one of the most common relations between people and forests (Khare et al. 2000), as food from the forest is a source of protein for many people (Gyimah and Dadebo 2010) since many plant species are sources of non-timber forest products (Timko et al. 2010).

The benefit, of one or more environmental services from forest services that support the livelihoods of people living in or near forests and their life rely on forest habitats, is considered to be forest-dependent people (Dubois 2003). The relationships between forest and forest- homed societies received attention by scientists and policymakers due to its significance for sustainable forest management and local livelihood (Adhikari et al. 2004; Mamo et al. 2007). The benefits of non-timber forest products is a possible means to improve rural livelihoods and conserve biodiversity in many forested areas of the world (Shackleton et al. 2005; Rasul et al. 2008). Many young people in the developing world may be more dependent on forest products (Godoy and Contreras 2001; Mamo et al. 2007), since the young may have multiple uses for the forests and feet for the labor-intensive work of the forest than elderly people (Cavendish 2000).

In developing countries, forest incomes performing an essential role for rural livelihoods, and have a significant role for local people to meet their subsistence need and generate income from forest products (Angelsen et al. 2014; Mukul et al. 2016). Academician gives a great concern, for the connection between the forest and the local, remote community for the intention of forests conservation and livelihood income. People in the remote area of developing countries was greatly depended on forests (Wen et al. 2017), to meet their daily needs (Mamo et al. 2007). From the empirical evidence in the glob the forestdependent community was too much and have their own power on frost conservation, for instance, $40 \%$ in Zimbabwe (Cavendish 2000), 38.82\% in Myanmar (Wen et al. 2017), and 30\% in Malawi (Fisher 2004) depend on forest resource to meet their daily needs.

The level of use and degree of support of forests to the local livelihood and its importance as a source of survival were varied geographically or across the communities (Babulo et al. 2008), this is because of the non-homogeneity of the community, however, it is a common practice that household reliance on forests (Córdova et al. 2013). The livelihood diversification has a grate, ecological conservation outcomes for the remote western community of Ethiopia, hence up to $39 \%$ of the forest resource is used to meet their daily needs and have a significant role than other income for the area (Mamo et al. 2007). Understanding the factors of households rely on forests for long-term sustainable forest management and conservation (Hegde and Enters 2000), is a fundamental step towards planning for specific interventions, policy development and ecological management strategies (Babulo et al. 2008; Dagm et al. 2016). The provisioning services from forests has been measured using a forest income approach nevertheless, there are a few nonincome benefits that the community benefited from. The rural households extract many forest products from the forest, but not much realistic evidence (Edmonds 2002). The forest of southwest Ethiopia is among the remnant Afromontum rainforest of the country and many indigenous communities were harmed, this area is untouched and endowed with many Fauna and Flora, moreover, Konter Coffee Biosphere reserve registered by UNESCO is found in this area.

Their livelihood nature of this indigenous community largely depended on the forest extracts, this may have a positive impact on forest conservation and hence this study may give some representative evidence of this area.

Therefore the objective of this study is to explore the empirical evidence of provisioning services role of remote forest homed communities of southwest Ethiopia.

\section{Methodology}

This study was conducted in the moist evergreen Afromontane forests of southwest Ethiopia, which is the home of many indigenous plants found in the area. It is located in Bench Maji Zone in, Southern Nations, Nationalities and People's Regional State of Ethiopia's (Fig. 1) within the geographic coordinates of $5.33^{\circ}$ to $7.26^{\circ} \mathrm{N}$ and longitudes from $34.88^{\circ}$ to $36.14^{\circ} \mathrm{E}$. The elevation of the area is ranging from 690 to 2500 metersabove sea level and it has a total area of 141,600 haof natural forest. It is found at a distance of $640 \mathrm{kmfrom}$ the capital of Ethiopia, Addis Ababa, found on the way to South Sudan along the river basin of Baro-Akobo which flows into South Sudan.

The article investigates the variation of forest utilization across households in three ethnic groups living near the forest area and the contribution of level forest income, at household level forest, that upkeep them to live in equipoise within the forest.

\section{Data collection and questionnaire design}

For forest income evaluation, in this paper, total income of the household was divided into four major and twenty sub-categories based on the Poverty Environment Network (PEN) survey instrument (PEN 2007a). Because PEN better for the village and household-level quantitative level questionnaires intended to stimulate comprehensive data about the importance and role of environmental income in rural livelihood (Vedeld et al. 2004; Vedeld et al. 2007), that address the income from 


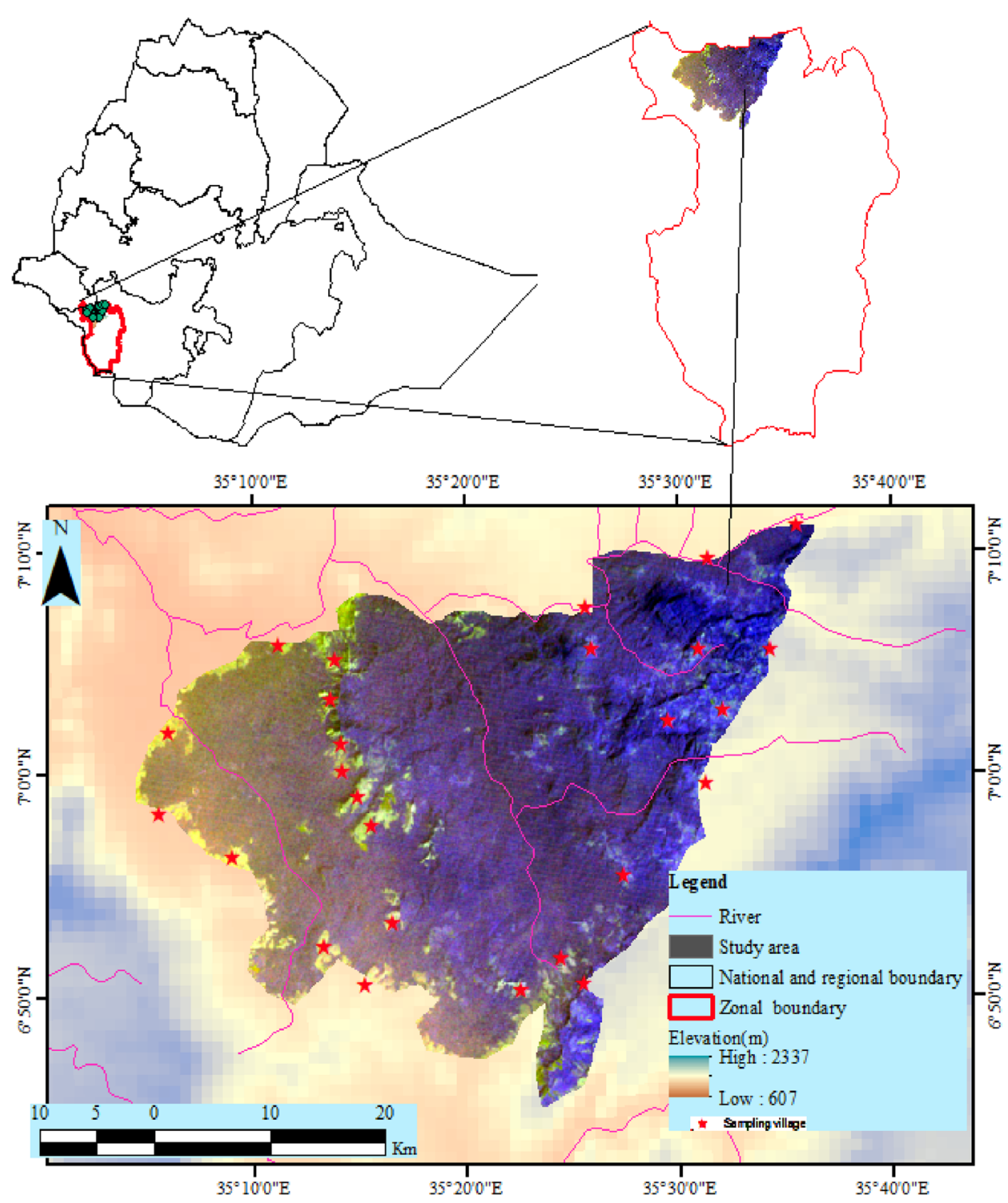

Figure1 Study area

two income sources corresponding to self-employment on forest in an unprocessed way (included, the harvesting of the products in the raw, and used or sold) and Income from self-employment of processed (value added) product (eg. Charcoal selling,timber wood processing) of forest.

We followed a systematic forest service's collection 'PEN' standards, guidelines and procedures to make accurate, reliable and valid results of the investigations (Babigumira 2011), based on this group discussion with the village heads and the representative were made and then forest-specific information were gathered, the questions were sequenced, information on seasonality of the product were collected, respondent were selected together the group representative, the consistency of the data were cheeked. The outliers were identified and removed using boxplot methods proposed by Tukey.

Based on our fieldwork and observation, we detected, ethnicity is a major factor influencing access to resources from the forest. Consequently, the community was categorized in to two groups centered on livelihood means of indicators (Table 1). The first one (C1) people (5438) who live within the forests that only cropping an average of $0.25 \mathrm{ha} /$ year, and mostly plowing maize, around the back yard (for whom the forest is the dominant land use in all directions from their home) these people are 
Table 1 Grouping of the households (\%) based on grouping Indicators

\begin{tabular}{|c|c|c|c|c|}
\hline \multirow[t]{2}{*}{ Indicators } & \multirow[t]{2}{*}{ Overall (250) } & \multicolumn{2}{|l|}{ Category } & \multirow[t]{2}{*}{$\mathrm{X}^{2}$ significance } \\
\hline & & $C 1(n=125)$ & $C 2(n=125)$ & \\
\hline Indigenous, forest-dweller & 56.8 & 99.3 & 1.96 & $136.2>0.01$ \\
\hline Non-indigenous, benefited from forest & 39.6 & 0.7 & 98.06 & $95.40>0.01$ \\
\hline Distance from Forest $>1 \mathrm{~km}$ & 35.1 & - & 86.2 & $86.70>0.01$ \\
\hline Farming trained (average 0.25 ha) & 57.2 & 100 & - & $141.3>0.01$ \\
\hline Cropping Farm size (average 1.5 ha) & 40.8 & - & 100 & $100.5>0.05$ \\
\hline Number of house with a metal roof & 4.8 & 0.7 & 10.8 & $6.750>0.01$ \\
\hline
\end{tabular}

local ethnics Meanite, Mejenger, and Sheko found in 14 villages in the sampling area. The second (C2) is those who live proximate to the forests and cultivate an annual crop of 1.5 ha, majority depended on growing maize on the actual filed (estimated to be 8363). This community is recently settled in the area by government-sponsored settlement program or coming elsewhere from every corner of the country.

We made GPS supported filed survey with the local administrative (43 kebels) and select 25 representative villages. Consequently we followed two approaches for data collection the first approach is a focus group discussion, from 34 to 49 discussants and we collect general information on the forest, the types of forest product used by the community from their collection diaries and ranking their choices on forest-based strategies, this used for to identify whether culture and ethnicity influence resource use decisions and the implication for forest conservation.

The second approach is a household face to face interview based on Poverty Environment Network.

(PEN 2007a) PEN prototype with a certain modified questionnaires, by the local vernacular languages (Meanite, Mejenger, Sheko, and Amharic) from randomly selected of 250 respondents during the focus group discussion from April to September 2019. The respondent age was varied from 34 to 85 year's but we assumed that older rural people have greater knowledge of the utilization and extraction of forest ecosystem services then purposely include the aged group during the interview process. We employed majorly, local market prices to estimate the monetary value, but also used willingness to pay approach for those not marketed in the local market. The study draws from the responses of the survey questionnaires and from focus group discussion, centered on the services of a forest-dwelling remote community in southwest Ethiopia in relation to individual service type.

\section{Forest related provisioning service}

Bee keeping and honey production are an important aspect of rural livelihoods, especially for the remote communities are the main source of income (Sheko, Mejenger and Menit). This community practiced mainly by hanging of traditional hives on the top of the tree and some were harvested through hunting, from the long aged hollow wood. Traditionally, this group was hanging an average of 53 hives (ranging from 20 to 700)/household. According to the recorded data (2018), the C1 community has 286,184 of which 114,474 were active beehives $(39.5 \%)$ which yield $7.6 \mathrm{~kg} /$ hive/year (range 5 to $18 \mathrm{~kg} /$ hive/year) of three round harvest. However, the second category (C2) has only 24,039 beehives, which is $2.87 /$ head, among these 16,026 beehives with bee but the other was empty. The majority of the farmers are constructing and hanging beehives by themselves and sometimes, hire to local skilled people to provide the service. One traditional beehive is 20 ETB this was converted into total bases and the harvesting cost per beehive was one and estimated three beehives per day were harvested. At this base, the current cost of daily labor in the area is 50 Birr this will be considered as the cost in addition to the traditional hives cost of this all accounts, $36 \%$ of the income from the harvest and then we considered all this to be the production cost. The income per head was multiplied by productivity/year and thereby the perspective local market price of honey $(90 \mathrm{ETB} / \mathrm{kg}$ ) and production costs were deducted. The beeswax data were collected from the local drink (Tij) by-product which is $8 \mathrm{~kg}$ of honey gives $1 \mathrm{~kg}$ of beeswax, with an estimated cost of $35.16 \mathrm{ETB} / \mathrm{kg}$. In addition the farmers in the midland (13 Kebles $\mathrm{C} 1$ group) of the forest area digging and harvesting averagely 6 litters of liquid honey from Stingless honey bees (Trigona spp.) this will be estimated 78 litter/year and the local cost of this honey is $120 \mathrm{ETB} /$ liter with harvesting cost of $15 \mathrm{ETB}$.

Forest grazing is a major source of livestock fodder in this specific area, however, some; researchers estimated the value of fodder derived from forest ecosystem by a value added method form the livestock product (Teketay et al. 2010; Nune et al. 2013; Yimer 2016). Conversely, 
we follow a direct valuation method, based on the total salable animal feed to the small cities that close to the forest area. The farmer in this region has practiced a cut and carry strategy of the animal feed and sale in the nearby town to generate income. For this evaluation, we selected small and large town that have a strategy remained indoors in a tie barn with, the whole time within and around the forest edge that gate the fodder from the surrounding forest. From the respondent interview the farmers, get a certain income with selling grass from the cut and carry system and seal (man load/day), an average of 15 ETB /load in the nearby market. Based on the respondent estimate the minimum sources of the animal feed from open grassy and shrubby area $(89 \%$ for $\mathrm{C} 1$ and $73.7 \%$ for $\mathrm{C} 2$ ) followed by agricultural crop residues mainly green maize stalk in the field (1.1 for $\mathrm{C} 1$ and $21.2 \%$ for C2), Semi forest (8.7\% for C1and and 4.3\% C2) however from dark forest was only $(2.2 \%$ for $\mathrm{C} 1$ and $1 \%$ for $\mathrm{C} 2$ ) this include herbaceous plant and grass found in the vacant space of the forest but no much fodder was harvested from the coffee investment area.

The local ethnics C1(Meanite, Mejenger and Sheko) have a trained to cut and sale the chopped grass to all cities 22 /day this was multiplied by 365 and the net price after the deduction of labor cost of $1 \mathrm{~h}$ (6.25 ETB based on $50 \mathrm{ETB} /$ day labor cost, then the net price was 8.75 ETB) per carry load spent for collection and selling. From the information collected and the respondent's estimate, the daily consumption per human load (carry load) of cattle are 2 , sheep and got 1 , horses, donkey and mule 2 fodder/day.

The household directly benefited from the forest have an average of cattle, 4.5 for $\mathrm{C} 1$ and 1.4 for $\mathrm{C} 2$, sheep and got 5 for $\mathrm{C} 1$ and 2 for $\mathrm{C} 2$, horses and donkey an average of 1 for $\mathrm{C} 2$ because $\mathrm{C} 1$ class, have not any trend for rearing this kind of animal (BMZAFD 2018). Based on this we multiplied the average animal count, by the minimum daily intake and with the daily price of fodder man per load finally converted in to yearly and then by the source share of the land cover dynamic.

During filed survey we bring into being that coffee is found everywhere but dominant above 800 m.a.c.l in the natural forest (NF, 83,126.6 ha) and semi-forest (SF, $25,571.6$ ha). Based on the zonal agriculture estimate almost all reachable of NF and 59.4\% SF was owned and harvested by local ethnics (Sheko, Mejenger and Menit which is belongs to $\mathrm{C} 1$ ) however, only $11.7 \%$ (NF) is considered to be unreachable because of belief and other factors (BMAD 2018). However, due to labor intensive, deepens and inaccessibility of the land, only one household harvest from 4 to 6 quintal of coffee from the NF (an average of 2 hectare) and $40.6 \%$ (SF) was possessed by $\mathrm{C} 2$ category. The productivity of coffee on natural forest estimated to be an average of 2.5qt/ha (Taye 2009) and the production cost for natural coffee in the NF for picking, 812.5 ETB /ha, but also farther, stringing, laying on the ground for five days and transporting in to the market needed additionally 300 birrs, based on this set-up 1123.5 $\mathrm{ETB} / \mathrm{ha}(0.44 \mathrm{~b} \mathrm{ETB} / \mathrm{kg})$ is being needed to accomplish the work of one hectare, that was a bit-difference 0.3 ETB per kg reported by others (Reichhuber and Requate 2007) and we considered the total coffee was being sold in the coffee bean with the current price $35 \mathrm{ETB} / \mathrm{kg}$. The net income of Natural forest is $7624.5 \mathrm{ETB} / \mathrm{ha} /$ year this was multiplied by the total harvested hectare of $\mathrm{C} 1$ category. However, the productivity of semi forest was $4.5 \mathrm{qt} / \mathrm{ha}$, but need much production cost as compared to the natural forest that include, thinning and some minor management (estimated additional cost of 720 ETB /year/ha) the total cost of production for semi forest estimated to be $1833.5 \mathrm{birr} / \mathrm{ha} /$ year. The productivity was $4.5 \mathrm{qt} / \mathrm{ha}$ and then the total yearly net income of semi forest coffee is $1833.5 \mathrm{ETB}$ is $13916.5 \mathrm{ETB} / \mathrm{ha}$ /year and then this was being multiplied by total hectare and by landholding ratio.

The most common spices in this area are Aframomum corrorima found both in NF and SF. From the respondent's, one household was harvested an average of $110 \mathrm{~kg} /$ year ( $\mathrm{C} 1$ group), however the new comers and settlers (C2) gain, only from SF, $20 \mathrm{~kg} /$ year. The current, market price was, $90 \mathrm{ETB} / \mathrm{kg}$, with a harvesting and drying cost of $11 \mathrm{ETB}$, then the final net cost was $79 \mathrm{ETB} / \mathrm{kg}$ this will be multiplied by the total harvested spices in relation to each category.

Most of the villagers in the study area are from the remote communities $(\mathrm{C} 1)$ and then identified more than 42 wild and Semi-wild edible fruit, 5 roots and tuber Species (climbers), and 12 herbaceous plants used as a vegetable. According to the respondent suggestion the harvesting season of this species was varied and this food is used as dietary supplements for C2 category, but only the wild fruit mostly children in the forest were consumed, but used as a staple food for the forest homed community (C1) for this reason at least one family members from the household, was visited the forest ranging from 5 to 8 times/week (average7) to collect forest goods and fresh products. In this case, the women also participated to collect root products in nearby areas, and children also used fresh fruit during filed activity. One trip collection weighing $5-10 \mathrm{~kg} /$ trip an average of $7.1 \mathrm{~kg} / \mathrm{day}$ among that $35 \%$ was tuber or root, $44 \%$ herbaceous vegetable type and $21 \%$ was fruit (fruit include the fruit consumption by children on the field). Except some but the majority of this forest product is not traded in the market and then we used a willingness' to pay method to value non marketed product. Most of this community found 
within and around the forest then the cost of collection reach an average two hours this converted into daily laborer payable amount and have a cost-share only $11 \%$ of the gain. The market value assigned for this wild food for fruit 7.5 vegetable 3.5, for root and tuber $5 \mathrm{ETB} / \mathrm{kg}$ based on the marketed and willingness to pay approach from the respondent.

Good service like wood fuel, wood for house construction and timber were computed based on modified PEN survey questionnaires, because these goods are used, sold and purchased as a marketable product. We estimate full wood centered on daily consumption, since the consumption of one household (4.53 families) estimated an average of 1 women's load/4 days. Households within the forest and the edge have not any trend to use charcoal to meet their energy needs, however, $\mathrm{C} 1$ community, used as a source of income, transported and sold in the nearby 11 markets. Based on their estimate, 2 women's load (40 kg/market/day) sold with an average of $140 \mathrm{ETB} / \mathrm{load}$ and the production cost estimated 1 person/day, which is 50 ETB (8030/women's load/year which is 562100 ETB) to the local market and this divided by/the number of housed hold benefited.

The construction materials benefited from the forest was computed directly from the respondent's estimate. There are 43 Keble's within the extent of the forest, annually 3 new-houses and 2 old houses were constructed and repaired respectively. The total round wood needed for one new house were $6.75 \mathrm{~m}^{3}$ and one-fourth of this is enough for old house repairing $\left(1.6875 \mathrm{~m}^{3}\right)$.

The estimated cost of this construction material $1250 \mathrm{ETB} / \mathrm{m}^{3}$, based on this approximation $1,088,437.5$ ETB for new house construction and 181,406.2 ETB, for old houses repairing were required. No other roofing materials used than thatch grass in the area, thus we assumed that, the type of roofing material used by every household where thatch grass. The average estimation required for one new house construction to thatching the top was an average of 25 man carry load, and one fifth of this was enough for repairing the old house. The current market cost of this thatch grass was, $50 \mathrm{ETB} /$ carryload and we assumed that $2 \mathrm{~h}$ required for chopping and transporting of the materials, and this estimated to be 12.5 ЕTB and then the net cost were 37.5 ЕTB.

Based on the information from the respondent, every house were replacing by new thatch grass for every three years, and one-third of the household roof changed by new grass (4600), the total extract of thatch grass value was estimated based on the total thatch। roofing carry man's load. People also used timber wood that's used for furniture and other; consequently, we estimated the timber volume based on the known species Cordia africana. These species used in the area for timber production. However, transported timber wood to the central market is negligible but, there are 44 furniture and wood working shop that, found in 11 cities which benefited timber from the forest. One shop bay and used 6 Cordia africana, with an average cost of $143 \mathrm{ETB} /$ piece/week. This converted into yearly and multiplied by the number of shops to get the total timber harvested from the forest. Totally 264 /week pieces of timber or 37.7/day harvested (estimated to be 5393 ETB/day or 1,968,497/year), still only the local community participated in timber harvesting and benefited in relation to this extract.

The traditional health practitioners (THP) benefited from the forest in Guraferda 46, sheko 55 and Bench 22 which is 114 in total, (102 from the local ethnics, C1 but only 12 considered to $\mathrm{C} 2$ category). Intended to this we select 70 THP to make a deep interview and they respond that more than 108 types of plants used for to treat human and animal diseases treatment used for curing, typhoid fever, cancer, birth control, a broken bone, snake bits, healing wound, for fattening animals, for milking, skin-related diseases, Intestinal parasitic, respiratory tract infections, eye disease, retained placenta, toothache, abortion and to make fearlessness of the worries. These healer plants collected from the forest, grasslands and open fields within the forest boundary. Each THP visited by patients ranging from 5 to 12 (average 7) within a month. The patient paid ranging from 5 for skin diseases to 100 ETB for the medicine to make fearlessness so we exclude the outliers, take the average income of respondent's estimate per patient of $23 \mathrm{ETB}$, this multiplied the number of patients and THP then converted into year. For all medicinal product half day for collection and processing required this estimated to be $14.5 \%$ of the final outcome cost. Totally $220,248(23 \times 7 \times 12 \times 114)$ ETB then the net value was 188,312 and $1651.8 \mathrm{ETB} / \mathrm{THP}$ this assigning to the given $(\mathrm{C} 1$ andC2)community category.

The women's and teenagers (from $\mathrm{C} 1$ and $\mathrm{C} 2$ ) have a trained to collect "ensosela" used for decorating the skin with color at a time of holyday and annual ceremony, the respondent estimated, that, an average of three times/ year/household which is an average cost of 20 ETB with a laborer cost of 2 ETB. The estimated, net value were 18 ETB/year, used for beautification and sometimes sold to the nearby market.

The Rhamnus prinodides (Gesho) found on the border of the forest and we assumed all communities benefited from this product since used for preparing local drinks. This were marketed in the local market, a range of 5-7 women carry load /week, sold with an average 20 birr/load and a total labor price estimated to be 3ETB/ women's load then the net price is 17ETB this multiplied by the total market (11 markets around the forest) and 
the number of weeks $(6 \times 54 \times 17 \times 11=60,588 \mathrm{ETB} /$ year). Finally, this valuation divided by the number of the household to gate at the home level.

The income from baskets made from lines (Kanta) were one of the forest products in the area, accordingly, the rural women $(\mathrm{C} 1)$ carry their goods by local basket (Kanta), this is available in every local market and sold by 50 ETB and the labor cost estimated to be 10.4 ETB (net price of 39.6ETB). An average 2 basket/market-day sold in 11 markets, 22/week) which estimated to be $47,044.8$ ETB/year. However, the basket also used as a container for carrying services for the local community. Accordingly the respondent, estimated one basket served for 2 years based on this notion, at least half of the local community $(\mathrm{C} 1,2719)$ was estimated to be change the old into new Kanta, but we assumed that the baskets sold during each market day (1188) bought by the same community in addition to 1531 made by themselves, because no other person in the area used this material or not transported elsewhere, this all gives 19.8 ETB/household/ year.

The villagers also used mats an average of 2 per year/ household and the local cost of this mate were $65 \mathrm{ETB}$, which is the estimated labor cost of $21 \mathrm{ETB}$ (net $44 \mathrm{ETB}$ ) an average 3 mat sold/market day that made by the local community $(\mathrm{C} 1)$. This computed as the same technique of basket above, then $88 \mathrm{ETB} /$ year/household expected.

Moring Tea (Chemo) the main drink like coffee in the area thus, the local community $(\mathrm{C} 1)$ in and around the forest has a much trend to use Chemo as a beverage, but they used twinges and the leaves like green tea after boiling, this is a common practice on every household in the rural area and a common gusting ceremony of every community around the forest but $\mathrm{C} 2$ used coffee from the harvested lot. According to their estimate, much of the twinges harvested from semi forest (55\%), forest (29\%), and the rest from agriculture around the farmyard (16\%).

Every family members used Chemo at least two cup/ day (morning and afternoon) and this multiplied by the total population benefited from the forest then by two and converted into the year. One cup sold in a local market by 1 ETB and we reduced a labor and ingredient cost 0.25 ETB which is a net price 0.75 ETB.C1, means (4.53 $\times 2 \times 0.75) \times 365=2480.2$ /household.

Agricultural income were other source of income, based on the data of zonal agricultural department (BMAD 2019) and field observation, the community around the edge of natural forest are dominantly cultivated maize with the level have an access of land but only cropping on average 0.25 ha/year which is a productivity 18 quintal/ha $(\mathrm{C} 1)$. The other farmers $(\mathrm{C} 2)$ in this region are majorly dependent on filing crops they cultivate an average 1.5 ha of which $0.98 \%$ land is cultivated with fertilizer and improved seed (productivity 32 quintals/ha of maize), mostly this community is coming from somewhere else by settlement program. Accordingly, the income from the field crop was estimated based on the $\mathrm{C} 1$ and $\mathrm{C} 2$ category with the current market price of $1000 \mathrm{ETB}$ /quintal in 2019 market price. The production cost of this activity were estimated $6155 \mathrm{ETB} / \mathrm{ha}$ from the respondent's estimate. However, the maize cultivated with input needs additional cost for seed 118.75 ETB(193.75-75 ETB), for fertilizer 2390 ETB(DAP and UREA) and for transporting of the additional production and input $160 \mathrm{ETB}$ which cost a total of $8683.75 \mathrm{ETB} / \mathrm{ha}$.

The community benefited from bush meat were determined based on household-level, an average of 4 wild (a hen) birds 2 small animals were hunted per household (big animal like buffalo where hunted really) by the local ethnics (C1) but only one small animal/year/household were by the $\mathrm{C} 2$ category. They estimated the local market prices of 60 and 270 ETB with hunting cost 12 and 70 for wild birds and small animals, respectively.

According to the respondent's estimate, the income from daily duties like doing of a day laborer and traditional gold mining estimated an average $2600 \mathrm{ETB}$ /year for $\mathrm{C} 1$ community), however, the other category (C2) doing extra work like dealing small scale retail business (trade) and earned an average 18,124 ETB/household/ year.

The income stated from livestock was from milk product, the average annual income/household for $\mathrm{C} 1 \mathrm{com}$ munity where $1200 \mathrm{ETB}$ and from animal sale $400 \mathrm{ETB} /$ year total $5200 \mathrm{ETB} /$ year/household and also for C2 where estimated of $3800 \mathrm{ETB} /$ year/household.

\section{Approach and data analysis}

There are the different approaches of computing forest provisioning services the most one is dependency-based valuation, of which, forest dependency indexes (FDI) and relative forest income (RFI) approach are frequently used methods. However, a FDI relative index used to only compare household forest dependency, within the given sample, to evaluate and compare countries (Mirza and Szirmai 2010; Howe et al. 2014), but the intention of this study focused, on the general forest product benefit for the overall forest community of the area and the practices of harvesting forest products (forest use) and measure the magnitude of forest use as an economic insurance that support for consumption and a means of poverty reduction (forest reliance) to the total livelihood. For this reason we calculate the relative value for a given household income, that, forest needed for on the-going livelihood strategies (forest dependency) associated with forests is fundamentally measured using a relative forest income (RFI) approach, additionally household-level 
absolute forest income (AFI) also computed. This all were evaluated based on modified, worldwide analysis by the Poverty Environment Network of the Center for International Forestry Research questionnaires. The quantitative data of the cash from forest product sale (forest cash income) and all consumed forest products market value (Subsistence forest Income) administered based on the respondents reply of face to face interviews used by modified PEN questionnaires downloaded from the PEN web site (http://www.cifor.org/pen/).

The income definition in this study is based on the defined in the PEN technical guidelines (PEN 2007b). This income were computed with gross value acquire from the extraction of raw materials or services from the forest, agriculture, Livestock and Off-farm activities minus labour costs, with related activities.

As a result the total income where computed based on the following Eq. 1

$$
\mathrm{TI}=\mathrm{FI}+\mathrm{AI}+\mathrm{LI}+\mathrm{OI}
$$

where TI, House hold total income, FI, Forest income, AI, agriculture income, LI, Livestock income and OI, other income.

The role of forest provisioning ecosystem services (total forest income) to the community ( TFI)' were computed based on the following equation (Eq. 2) from the respondent) within Tukey HSD (honesty significant difference) procedure to make pairwise comparisons of the mean with in the same category. This was helpful for the ratio hypothesis (RFI) to estimate which income source contributed more to the total livelihood. We employed, the chi-square test for a fixed-ratio hypothesis and to analyze the differences in mean across the group of the community category because chi-square statistic is a test statistic for categorical variables.

\section{Result and discussions}

\section{Demographic characteristic of the sample population}

The community directly benefited from the forest were 5438 household (4.53 family size) was local ethnics (Meanite, Mejenger, and Sheko) and 8363 household (4.2 family size) were coming anywhere, but the selected respondent varied in ratio and in gender distribution which is $86.2 \%$ were male and $13.4 \%$ were female, from the respondent $50.4 \%$ were local ethnicities (Megengr, sheko and Menite) which is C1 category and all of this households were born in and around the forest. The second category of C2 was accounts $49.6 \%$, they are coming from somewhere else in the country, and not born in the current place. From the respondent $72.5 \%$ was not educated, but $19.5 \%$ having the primary level of education, whereas $8 \%$ have attained a secondary level of schooling.

$$
T F I=H B I+F G I+C I+F S I+F F V I+F W I+C I+C M I+T G I+T W I+M P I+M G I+M B I+M T I+B M I
$$

where TFI, Total forest income, HBI. Honey and beeswax income, FGI, Forest grazing income, CI, forest Coffee income, FSI, Forest spices income, FFVI, forest fruit and vegetables income, FWI, full wood income, CI, charcoal income, CMI, Construction material income, TGI, Thatch grass income TWI, income from timber wood, MPI, Medicinal Plant income, MGI, miscellaneous good income, MBI, Mats and Baskets income, MTI, Moring Tea (Chemo) and BMI, Bush meat income.

Relative forest income (RFI) was one method using to compute the forest share of net income, based on this we used this approach to measure forest dependence.

$$
\mathrm{RFI}=\frac{\mathrm{TFI}}{\mathrm{TI}}
$$

where RFI is relative forest income, TI, is house hold total income and TFI total forest income.

\section{Statistical test}

To make more accurate and to reduce underestimate/ overestimate on the requirement of forest income by RFI method, analyzed using SPSS 19.00 with ANOVA F-tests (p-value, $<0.01$ ) followed by mean test (for data collected
Contribution of forest related income associated with socioeconomic characteristics.

The (ANOVA) test indicated that, there was a significant difference $(\mathrm{p}<0.05)$ within the income source of the same group and between different category of the same product sources this leads to mean variation between the

\begin{tabular}{|c|c|c|c|c|c|}
\hline \multirow[t]{2}{*}{$\begin{array}{l}\text { Source } \\
\text { of income }\end{array}$} & \multicolumn{2}{|c|}{$\begin{array}{l}\text { Within the group } \\
\text { Mean }\end{array}$} & & \multicolumn{2}{|c|}{$\begin{array}{l}\text { Between group } \\
\text { Mean }\end{array}$} \\
\hline & $\mathrm{C} 1$ & $\mathrm{C} 2$ & & $\mathrm{C} 1$ & $\mathrm{C} 2$ \\
\hline Forest & $93,559.7^{a}$ & $27,448.3^{m}$ & & $93,559.7^{d}$ & $27,448.3^{e}$ \\
\hline Agriculture & $1625.7^{c}$ & $39,316.2^{n}$ & & $1625.7^{f}$ & $39,316.2^{9}$ \\
\hline $\begin{array}{l}\text { Off-farm activi- } \\
\text { ties }\end{array}$ & $2600^{c}$ & $18124^{\circ}$ & & $2600^{h}$ & $18124^{i}$ \\
\hline \multirow[t]{2}{*}{ Livestock } & $5200^{b}$ & $3800^{p}$ & & $5200^{j}$ & $3800^{j}$ \\
\hline & & & Sub total & $102,985.4^{r}$ & $88,688.5^{\mathrm{s}}$ \\
\hline
\end{tabular}

Table 2 Comparison of mean incomes based on source of product (household/year, ETB)

Mean comparison with Tukey HSD, procedure the superscripted letters from ' $a$ ' to ' $c$ ' and ' $m$ ' to ' $p$ ' indicated the mean (vertical) difference within the group but letters ' $d$ ' with ' $e$,' ' $f$ ' with ' $g$ ', ' $h$ ' with ' $i$ ' and ' $r$ ' with 's' specified the mean comparison, between across the category(horizontal), and the same alphabetical letters indicated no significant difference between the mean, however, different letters indicated a significant difference between the mean at $5 \%$ significant level 
product (Table 2). The total native community ( $\mathrm{C} 1$ category) in the target area is 5438 households, the annual income of this group were 102,985.4 ETB/year/households (Table 2 and Fig. 2). However, forest where the major income sources than agriculture. Similarly many scholars specified that income derived from forest were a major source of income (Adhikari et al. 2004) and the forest dwellers communality tend to have majorly dependent on forest (Cavendish 1999; Quang and Anh 2006; Pyhala et al. 2006).

This study also confirmed the mean variation within the class and between the two social categories was also significant that, the income of the indigenous (C1) community from the forest were 3.45 folds than the income of C2 (nonindigenous) societies; however the income from agriculture were very low for the home-grown community, but the main income source for $\mathrm{C} 2$ groups (Table 3 and 4). Likewise, Coomes and Barham (1997); Coomes et al. (2004), mentioned that, household geographic location of the community influences to use and access to forest resources. Other researcher also stated the strong association between forest dwellers to forest than others no forest inhabitant groups (Agrawal 2001; Adhikari et al. 2004; Pyhala et al. 2006; Fisher et al. 2014; Neill 2006).

Coffee have high income sharer and contribute more from the forest product for indigenous community (Table 3 and Fig. 2),followed by fruit and vegetables, this households adopted forest and livestock livelihood based strategy than the newcomers. On the other households (C2 category, newcomers,) agriculture play a great role for livelihoods food security as compared to the forest depended, indigenous and forest-dwelling
Table 3 Annual average and Relative forest income (RFI) by forest income source on $\mathrm{C} 1$ and $\mathrm{C} 2$ groups in southwest Ethiopia Coffee forest

\begin{tabular}{|c|c|c|c|c|}
\hline \multirow[t]{2}{*}{ Income source from } & \multicolumn{4}{|c|}{$\begin{array}{l}\text { Net Income by category ETB }(1 \mathrm{ETB}=\$ \\
0.0366) / \text { household/year and RFI }(\%)\end{array}$} \\
\hline & $\begin{array}{l}\text { C1 (ETB) } \\
\text { Annual }\end{array}$ & RFI (\%) & $\begin{array}{l}\text { C2 (ETB) } \\
\text { Annual }\end{array}$ & RFI (\%) \\
\hline Honey & 9370.2 & 10.1 & 862.7 & 3.14 \\
\hline Stingless honey & 1.6 & 0.001 & - & 0 \\
\hline Beeswax & 734.08 & 0.78 & 65.1 & 0.24 \\
\hline Forest grazing & 310 & 0.33 & 61 & 0.22 \\
\hline Coffee & 54,773 & 58.5 & 16,839 & 61.34 \\
\hline Spices & 8690 & 9.26 & 1580 & 5.76 \\
\hline Fruit and vegetables & $12,607.6$ & 13.47 & 4081.6 & 14.87 \\
\hline full wood & 3128.4 & 3.34 & 3128.4 & 11.4 \\
\hline Charcoal & 105.1 & 0.112 & - & 0 \\
\hline Wood for house construction & 392 & 0.42 & 392 & 1.43 \\
\hline Thatch grass & 71.2 & 0.08 & 71.2 & 0.26 \\
\hline timber wood & 142.63 & 0.15 & 142.63 & 0.52 \\
\hline Medicinal Plants & 31.50 & 0.034 & 2.35 & 0.008 \\
\hline Miscellaneous goods & 22.4 & 0.023 & 22.4 & 0.082 \\
\hline Mats and Baskets & 107.8 & 0.115 & - & 0 \\
\hline Moring Tea(Chemo) & 2480.175 & 2.65 & - & 0 \\
\hline Bush meat & 592 & 0.63 & 200 & 0.73 \\
\hline
\end{tabular}

community (Table 4 and Fig. 3). Similarly to this study Tadesse et al. (2013) reported that, coffee was the major households income and forest based livelihood strategies are commonly adapted in south west Ethiopia forest homed community.

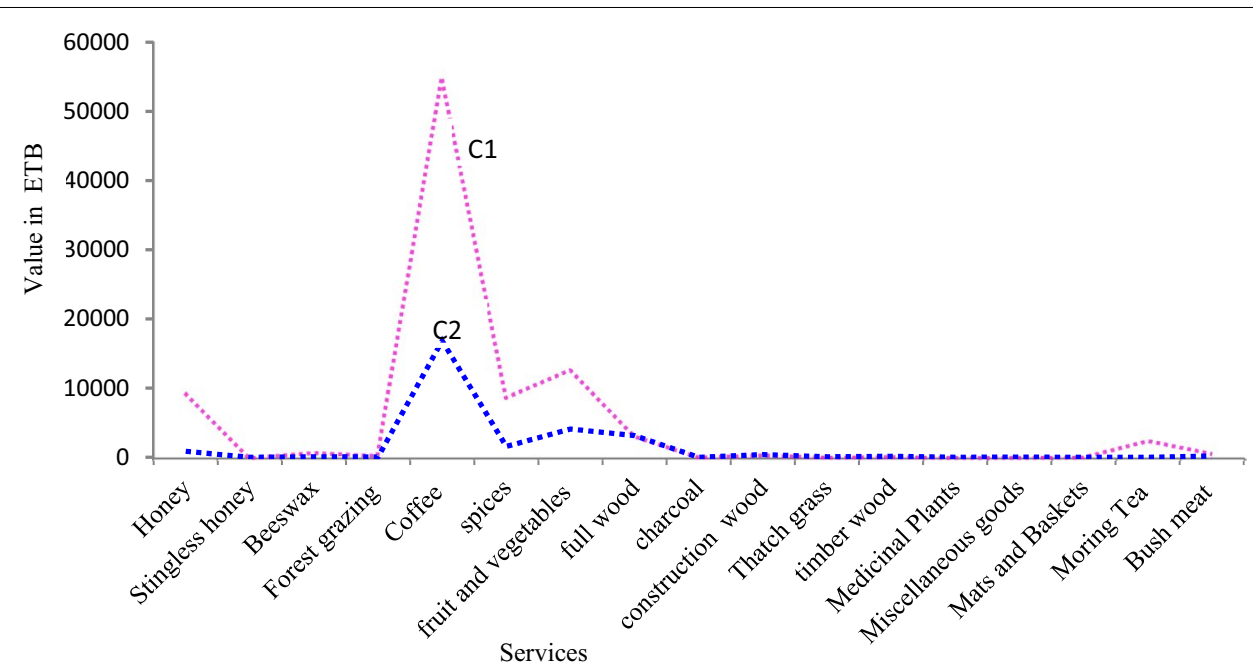

Fig. 2 Demonstrating of forest-related income sources to comparing the relative dimensions within 17 forest products and variation between category (collected by households/year, ETB) 
Table 4 Annual average and relative income (\%) from nonforest product

\begin{tabular}{llllc}
\hline Income from & \multicolumn{4}{l}{$\begin{array}{l}\text { Net Income by category ETB (1ETB= \$ 0.0366) } \\
\text { household/year }\end{array}$} \\
\cline { 2 - 5 } & $\begin{array}{l}\text { C1(ETB) } \\
\text { Annual }\end{array}$ & Rel(\%) & $\begin{array}{l}\text { C2 C1(ETB) } \\
\text { Annual }\end{array}$ & Rel (\%) \\
\hline Agriculture & 1625.7 & 17.3 & $39,316.2$ & 64.2 \\
Off-farm activities & 2600 & 27.53 & 18,124 & 29.6 \\
Livestock & 5200 & 55.17 & 3800 & 6.2 \\
\hline
\end{tabular}

The provisioning service of the forest to the local community were varied in relation to demographic features, the income from forest products for indigenous and forest-dwelling community $(\mathrm{C} 1)$ were shown to high as specified by RFI approach, to which contributes $90.85 \%$ followed by Livestock product $5.06 \%$, and off farm activity $2.52 \%$, however the contribution of agriculture to the livelihood were only 1.57\% (Table 5 and Fig. 4).

Indigenous community majorly depended on gathering of forest products to maintain their livelihood with a least of crop growing (Lu 2007; Siren 2007; Levi et al. 2009). Hence, comparable to our results the role of forest and extractive incomes play a great role for diversification, asset accumulation, and poverty mitigation in Malawi (Thabbie 2014). Many authors also suggest that, forest product contributed more as compared to the other product (see Davis et al., 2010; Vedeld et al. 2007) that to help to meet dietary and ceremonial needs (Belcher 2003; Maass et al. 2005) for the remote community. This demonstrated that much rural, remote community was dependent on forests and has a long history of the link between this livelihood and forest services.

While the dominant income (C2) for who have resettled and coming from another area of the country, were
Table 5 Relative forest income (\%)against the total sources of income for indigenous (C1) and introduced community (C2)

\begin{tabular}{llllll}
\hline No & Income source & \multicolumn{2}{l}{ Income } & & \\
\cline { 3 - 6 } & & C1(ETB) & RFI \% & C2(ETB) & RFI \% \\
\hline 1 & Forest & $93,559.7$ & 90.85 & $27,448.3$ & 30.95 \\
2 & Agriculture & 1625.7 & 1.57 & $39,316.2$ & 44.33 \\
3 & Off-farm activities & 2600 & 2.52 & 18,124 & 20.43 \\
4 & Livestock & 5200 & 5.06 & 3800 & 4.28 \\
& Total & $102,985.4$ & 100 & $88,688.5$ & 100
\end{tabular}

agricultural, which contributes $44.33 \%$, followed by $30.95 \%$ of forest and off-farm activities $20.43 \%$. This community is well skilled, more on agricultural systems, and received 27,448.3 ETB from agriculture as of the mean annual income of $88,688.5$ ETB. However the indigenous community received 93,559.7 ETB from forest per annum, which contributes an excessive share of mean annual income of 102,985.4 ETB.

The leading income sources of forest-dwelling community (C1) were coffee $54,773 \mathrm{ETB}$, followed by fruit and vegetables 12,607.6 ETB and honey, 54,773 ETB which is NTFP product (Fig. 2). Several studies on forest ecosystem conformed, many indigenous, forest-dweller community globally are reliant on forests for livelihood sustenance (World Bank 2002). Similar findings have been also observed in this region and confirmed that coffee is the leading income source followed by honey of this frost area (Chilalo and Wiersum 2011).

\section{Role of forests in livelihood sustenance}

The overall result from the local ethnics, C1 (Megengr, sheko and Menite) pointed that, the forest is a variety

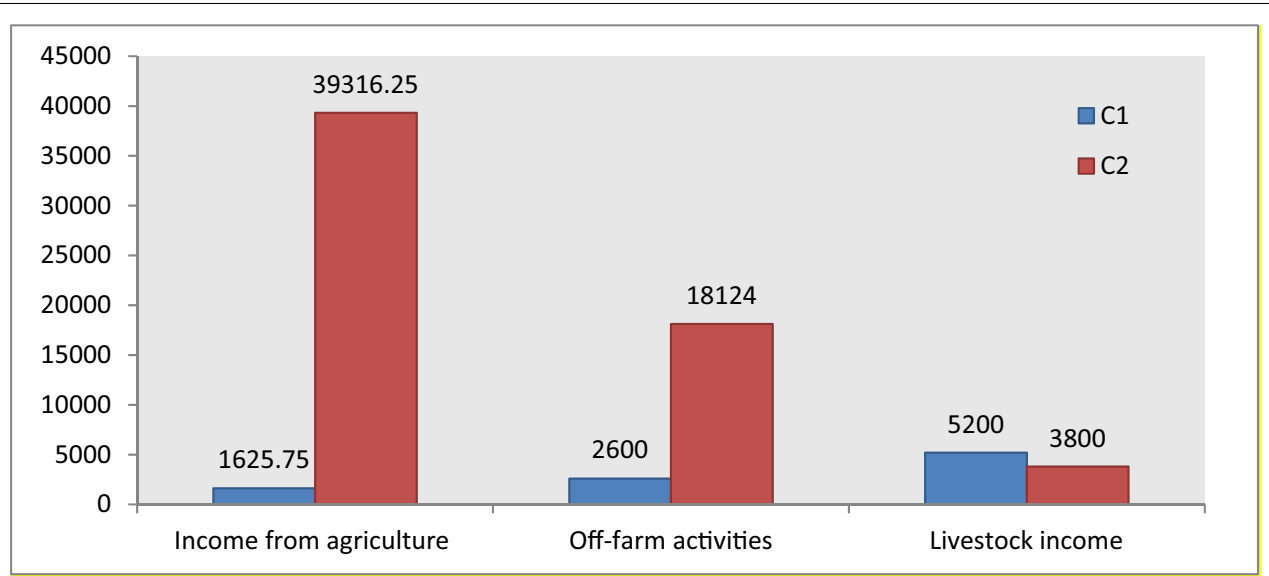

Fig. 3 The relative dimensions of Non-forest livelihood income by source and category (collected by households/year, ETB) 


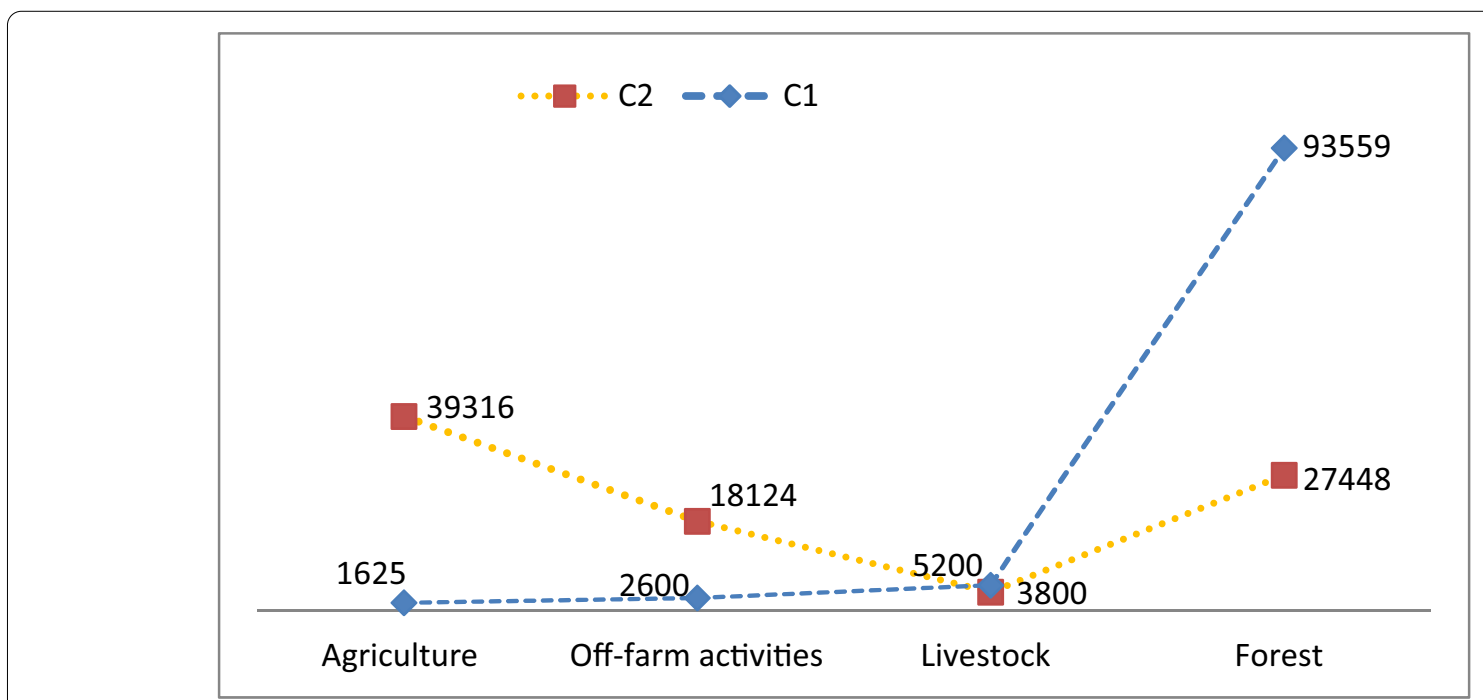

Fig. 4 Contribution of income source (ETB)

of ways, that is not only the source of revenue from the harvested product but also a reliance on the total survival needs, though, we hypothesize here that, the household forest dependence is the activities of forest product collection by users to meet the household needs and make forest as safety net function.

Thus, the annual income from the forest at household level were more contribute and a key livelihood strategy in the forest area (Fig. 4). The study of others also indicated, household reliance on forests, in the absence of alternatives were very high (Neumann and Hirsch 2000; Angelsen and Wunder 2003) and an approach a way used as out of poverty (Tadesse et al. 2013; Bwalya 2013). However, the socioeconomic characteristics of $\mathrm{C} 2$ group influenced to use the forest-based resources and indicated a forest-based livelihood have alternative income sources than forest-dwelling indigenous populations. Similarly other observation also reported, wild food harvested from the forest used as a gap fillers in times of regular seasonal deficits (Shackleton and Shackleton 2004; Paumgarten 2005; McSweeney and Jokisch 2007; Sawyer 2004).

The overall rural community, especially in this remote area those who lack of access for social support and infrastructure were majorly dependent on forests. Totally, 13,801 households (C1 and C2) where directly hinged on forest related products, which valued 738,327,781.5 ETB $(\$ 27,022,796.8)$ were harvested yearly from this remnant forest. This income folded 22 times from the annual capital budget of the three districts, but the agricultural income were only $563,408,749$ ETB this indicated simply accounts $43.2 \%$ as compared to forest income (Fig. 5 ).

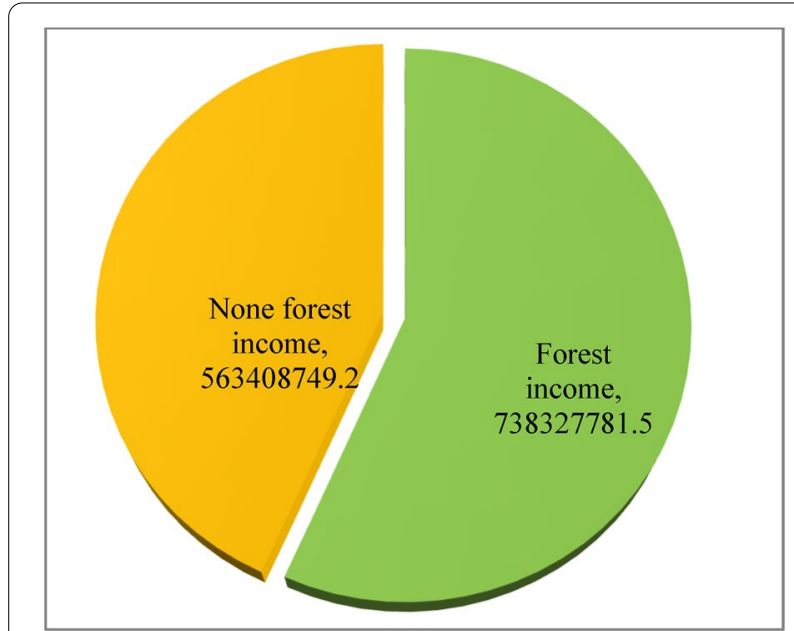

Fig. 5 Share of income sources in ETB/household/year

According to the researchers the rural households rely on wild natural resources to help to meet the current needs (FAO 2008; Neumann and Hirsch 2000). The analysis of other also suggested, several people in the world depended on forest derived products to satisfy subsistence needs, the majority in developing countries (Bahuguna 2000). Many studies also confirmed that $22 \%$ of the household income in developing countries contributed by forest (Vedeld et al. 2007).

Our results revealed that the contribution of forest resource was more for poorer households that living within the forest and generate a higher relative forest income from the proportion of household absolute forest income, and hence we considered that, forest 
Table 6 Attitude proportion of the households (\%) in for forest conservation stratified by household native category

\begin{tabular}{|c|c|c|c|c|c|c|}
\hline & \multirow[t]{2}{*}{ Description } & \multicolumn{2}{|c|}{$\mathrm{C} 1(\mathrm{n}=125)$} & \multicolumn{2}{|c|}{$C 2(n=125)$} & \multirow[t]{2}{*}{$\mathrm{X}^{2}$ significance } \\
\hline & & Agree\% & Disagree\% & Agree \% & Disagree\% & \\
\hline 1 & Having traditional forest conservation practices & 99.2 & 0.8 & 12 & 88 & $141.3>0.01$ \\
\hline 2 & A trends of long term harvesting of NTFP product & 100 & 0 & 44 & 56 & $93.7>0.01$ \\
\hline 3 & Attitude to stop expansion agriculture & 99.2 & 0.8 & 1.6 & 98.4 & $39.0>0.01$ \\
\hline 4 & Attitude to stop harvesting of timber related product from the forest & 79.2 & 20.8 & 44 & 56 & $32.4>0.01$ \\
\hline 5 & Having traditional and religious relation with the forest & 71.2 & 28.8 & 2.4 & 97.6 & $126.8>0.01$ \\
\hline 6 & Considering the forest as belongs to them & 77.6 & 22.4 & 31.2 & 68.8 & $54.2>0.01$ \\
\hline 7 & Attitude towards having the responsibility to protect the forest & 92 & 8 & 27.2 & 72.8 & $97.6>0.01$ \\
\hline
\end{tabular}

provisioning service influenced by ethnic identity and culture. Remoteness was the key determinant of a household's engagement for sale and a source of revenue from the forest. But agriculture was the main source of income for those settling recently in the area. The contributions of non-timber forest products for local ethnics have high as compared to timber forest product, this may have positive consequence for forest conservation.

\section{Matching of forest use and reliance to forest conservation}

The forest is the dominant land use in all directions and described as a form of economic insurance (reliance) for the community of $\mathrm{C} 1$ (Table 5). Almost all of the respondent from $\mathrm{C} 1$ category has been a trend to use the forest without more damaging the timber product expect the recent learned trained which is timber harvest and charcoal production. We found that the contributions of non-timber forest products (honey, stingless honey, beeswax, coffee, spices, fruit and vegetables, thatch grass, medicinal plants, miscellaneous goods, morning tea, and bush meat) were $87.2 \%$ as compared to ecologically destructive product (12. 8\%, like timber harvest). However, we observed a reversible trained on $\mathrm{C} 2$ category of which $53.3 \%$ of the income has been received from ecologically destructive sources. The traditional habit of the indigenous populations also another positive effete for forest conservation, since that, they consider the forest are upper land, which is more honey harvested and the daily consumption was also generated. Furthermore, they accept as a true of the ancestor believes, since they considered the aged forest as a superpower, forest cutting may have a negative consequence on health case blotting, and harm the generation life even after death. Corresponding to our observation many opinion recommended that, traditional Culture and indigenous knowledge have a positive effect for forest and wildlife conservation and has received a great consideration to day (Schroeder and González 2019; Yuan et al. 2012).
Indigenous peoples have long associations with natural forest and a deep understanding of it. This indicated that there is no inherent conflict between the conservation of forest and their daily needs harvested in the forest. To do that the responsible body should encourage this traditional person and made market facilities, especially for the NTFP harvested product (honey, coffee, Korerima etc.). Forest for the traditional and the indigenous communities used for access to a finite resource and considered the resource harvested from the forest is the base of economic insurance. Almost all the indigenous community are less destructive proportion trends on the natural resource harvested from and willingness to stop the destructive practice (Timber and Charcoal production) (Table 6). The community also has a long history that sharing from their ancestor to preserve the natural forest, for the purpose as a cultural and spiritual sites. So the harvesting of resources for the natural forest was well matched and we considered as a safeguard for this remnant forest. Many relevant studies also indicated forest$\mathrm{dwelling}$ indigenous peoples have lower environmental impacts than non-indigenous peoples living in the same areas (Adeney et al. 2009; Asner et al. 2005; Blackman et al. 2017; Holland et al. 2014; Nolte et al. 2013).

\section{Conclusion}

Currently Forest ecosystem service, as the target of investigation for forest conservation and development programs. This study explores the role of forest provisioning ecosystem services to the rural households and evaluates this contributions to the households annual incomes hence, the provisioning service of the forest to the local community varied in relation to demographic features, the income from forest products for indigenous and forest-dwelling community shown to high as specified by RFI approach, to which contributes $90.85 \%$ from the total income. This remote community was dependent on the forest and have a long history of link between this livelihood and forest. While forest also provides a considerable 
income for the new resettled community coming from elsewhere in the area. This result indicated that the contribution of forest resource was more for poorer households and the economic insurance for the people, who live within the forests. Likewise the indigenous populations have another positive effect for forest conservation, since that, they consider the forest as belongs to them in relation to their ancestral beliefs, hence believed that, forest cutting may have a negative consequence on their generation life even after death. We conclude that forest for the traditional and the indigenous communities used for access to a finite resource and considered the resource harvested from the forest are the central part of their economy and the relationships between forests and people's livelihoods particularly for this remote community were complementary. Then planning should take into conceder, in policy perceptive, for supporting this remote community for livelihoods improvement and conservation of this natural forest.

\section{Acknowledgements}

We would like to acknowledge the Centre of Environmental Science Program Addis Ababa University for providing us with financial and for the overall logistical support. We are appreciative also the Ethiopian Meteorological Services Agency for offering of time series meteorological data. We acknowledge the Tapi Spice Research Center for their support and provided us supplementary materials for the general information of the crop. Finally, we acknowledge, the editors and an anonymous reviewer for helpful and constructive comments of this article.

\section{Authors' contributions}

AF. Performed the study design, data collection, data interpretation, and writing the manuscript. TS and BWD Performed the study design, Conceptualization, draft review and edit of the manuscript. All authors read and approved the final manuscript.

\section{Funding}

No any funding has been received for this study.

\section{Ethics approval and consent to participant}

Not applicable.

\section{Consent to publication}

Not applicable.

\section{Competing interests}

The authors have no competing interest to declare.

\section{Author details}

${ }^{1}$ Center of Environmental Science, Addis Ababa University, P.O. Box 1176, Addis Ababa, Ethiopia. ${ }^{2}$ Department of Plant Biology and Biodiversity Management, Addis Ababa University, P.O. Box 1176, Addis Ababa, Ethiopia.

Received: 3 December 2020 Accepted: 6 February 2021

Published online: 22 February 2021

\footnotetext{
References

Adeney JM, Christensen NL Jr, Pimm SL (2009) Reserves protect against deforestation fires in the Amazon. PLoS ONE 4(4):e5014. https://doi. org/10.1371/journal.pone.0005014

Adhikari B, Falco SD, Lovett JC (2004) Household characteristics and forest dependence: evidence from common property forest management
}

in Nepal. Ecol Econ 48:245-325. https://doi.org/10.1016/j.ecole con.2003.08.008

Agrawal A (2001) Common property institutions and sustainable governance of resources. World Dev 29(10):1649-1671. https://doi.org/10.1016/50305 $-750 \times(01) 00063-8$

Angelsen A (2007) Forest cover change in space and time: combining the von Thu" nen and forest transition theories. In: Angelsen A, Wunder S. World Bank Policy Research Working Paper 4117. https://doi. org/10.1596/1813-9450-4117.

Angelsen A, Wunder S (2003) Exploring the forest-poverty link: key concepts, issues and research implications. In: CIFOR Occasional Paper. https://doi. org/10.17528/cifor/001211.

Angelsen A, Jagger P, Babigumira R, Belcher B, Hogarth NJ, Bauch S, Borner J, Smith-Hall C, Wunder S (2014) Environmental income and rural livelihoods: a global-comparative analysis. World Dev 64:S12-S28. https://doi. org/10.1016/j.worlddev.2014.03.006

Asner GP, Knapp DE, Broadbent EN, Oliveira PJ, Keller M, Silva JN (2005) Selective logging in the Brazilian Amazon. Science 310(5747):480-482. https:// doi.org/10.1126/science.1118051

Babigumira R (2011) Data entry and quality checking. In: Angelsen A, Larsen HO, Lund JF, Smith-Hall C, Wunder S (eds). Measuring livelihoods and environmental dependence. Methods for research and fieldwork. Earthscan.

Babulo B, Muys B, Nega F, Tollens E, Nyssen J, Deckers J, Mathijs E (2008) Household livelihood strategies and forest dependence in the highlands of Tigray. Northern Ethiopia Agric Syst 98(2):147-155. https://doi. org/10.1016/j.agsy.2008.06.001

Bahuguna VK (2000) Forests in the economy of the rural poor: an estimation of the dependency level. AMBIO A J Human Environ 29(3):126-129. https:// doi.org/10.1639/0044-7447(2000)029

Belcher BM (2003) What isn't an NTFP? Int For Rev 5(2):161-168

Belcher BM, Schreckenberg K (2007) NTFP commercialization: a reality check. Development Policy Review 25(3):355-377. https://doi.org/10.5897/ JHF2013.0305

Blackman A, Corral L, Lima ES, Asner GP (2017) Titling indigenous communities protects forests in the Peruvian Amazon. Proc Natl Acad Sci 114(16):41234128. https://doi.org/10.1073/pnas.1603290114

BMAD ( Bench Maji zone Agricultural department) (2018) Coffee and Annual Crop, 2018 annual report, Mizan Tefri , Ethiopia

BMAD ( Bench Maji zone Agricultural department) (2019) Coffee and Annual Crop, 2019 quarterly report, Mizan Tefri, Ethiopia

BMZAFD (Bench Maji zone Animals and Fisheries department) (2018) Livestock and Fisheries, 2018 annual report, Mizan Tefri, Ethiopia

Bwalya SM (2013) Household dependence on forest income in rural Zambia. Zambia Soc J 2(1):67-86

Cavendish W (1999) Incomes and poverty in rural zimbabwe during adjustment: chivi communal area, 1993/94 to 1996/97. University of Oxford, Centre for the Studies of African Economies

Cavendish W (2000) Empirical regularities in the poverty- environment relationship ofrural households: evidence from Zimbabwe. World Dev 28:1979-2000. https://doi.org/10.1016/S0305-750X(00)00066-8

Chilalo M, Wiersum K (2011)The role of non-timber forest products for livelihood diversification in Southwest Ethiopia. Ee-JRIF Vol 3, No 1 2011agriculture and forestry issue: $\mathrm{pp} 44-59$.

Coomes OT, Barham BL (1997) Rain forest extraction and conservation in Amazonia. Geogr J 163(2):180-188

Coomes OT, Barham B, Takasaki Y (2004) Targeting conservation-development initiatives in tropical forests: insights from analyses of rain forest use and economic reliance among Amazonian peasants. Ecol Econ 51:47-64. https://doi.org/10.1016/j.ecolecon.2004.04.004

Cordova JPP, Wunder S, Smith-Hall C, Borner J (2013) Rural income and forest reliance in highland Guatemala. Environ Manag 51(5):1034-1043. https:// doi.org/10.1007/s00267-013-0028-6

Dagm F, Wubalem T, Abdella G (2016) Economic Contribution to Local Livelihoods and Households Dependency on Dry Land Forest Products in Hammer District. Southeastern Ethiopia. Int J For Res 2016:5474680. https ://doi.org/10.1155/2016/5474680

Davis B, Winters P, Carletto G, Covarrubias K, Quinones EJ, Zezza A et al (2010) A cross-country comparison of rural income generating activities. World Dev 38(1):48-63. https://doi.org/10.1016/j.worlddev.2009.01.003 
Dubois O (2003) Forest-based poverty reduction: a brief review of facts, figures, challenges and possible ways forward. In: Oksanen T, Pajari B, Tuomasjukka T (eds) Forests in poverty reduction strategies: capturing the potential. European Forest Institute, European Forest Institute (EFI) Proceedings No. 47. pp 65-81.

Edmonds EV (2002) Government-initiated community resource management and local resource extraction from Nepal's forests. J Dev Econ 68:89-115. https://doi.org/10.1016/S0304-3878(02)00007-X

FAO (2008) Links between national forest programmes and poverty reduction strategies. In: Forestry policy and institutions working paper 22. Rome: Food and Agriculture Organisation of the United Nations.

Fisher M (2004) Household welfare and forest dependence in Southern Malawi. Environ Dev Econ 9:135-154. https://doi.org/10.1017/S1355 $770 \times 03001219$

Fisher JA, Patenaude G, Giri K, Lewis K, Meir P, Pinho P, Rounsevell MD, Williams $M$ (2014) Understanding the relationships between ecosystem services and poverty alleviation: a conceptual framework. Ecosyst Serv 7:34-45. https://doi.org/10.1016/j.ecoser.2013.08.002

Godoy R, Contreras M (2001) A comparative study of education and tropical deforestation among lowland Bolivian Amerindians: forest values, environmental externality, and school subsidies. Econ Dev Cult Chang 49(3):555-574. https://doi.org/10.1086/452515

Gyimah R, Dadebo M (2010) Mapping of key forest governance reform in Ghana and the role of growing forest partnerships (draft). Forestry Commission, Ghana

Hegde R, Enters T (2000) Forest products and household economy: a case study from Mudumalai Wildlife Sanctuary. Southern India. Environ Conserv 27(3):250-259. https://doi.org/10.1017/S037689290000028X

Holland MB, De Koning F, Morales M, Naughton-Treves L, Robinson BE, Suárez $L$ (2014) Complex tenure and deforestation: implications for conservation incentives in the Ecuadorian Amazon. World Dev 55:21-36. https://doi. org/10.1016/j.worlddev.2013.01.012

Howe C, Suich H, Vira B, Mace GM (2014) Creating win-wins from trade-offs? Ecosystem services for human well-being: a meta-analysis of ecosystem service trade-offs and synergies in the real world. Glob Environ Chang 28:263-275. https://doi.org/10.1016/j.gloenvcha.2014.07.005

Khare A, Mayers J, Morrison E (2000) Joint forest management: policy, practiceand prospects. London, IIED

Levi T, Shepard GH Jr, Ohl-Schacherer J, Peres CA, Yu DW (2009) Modelling the long-term sustainability of indigenous hunting in Manu National Park, Peru: landscape-scale management implications for Amazonia. J Appl Ecol 46(4):804-814. https://doi.org/10.1111/j.1365-2664.2009.01661

Lu F (2007) Integration into the market among indigenous peoples: a cross cultural perspective from the Ecuadorian Amazon. Curr Anthropol 48(4):593-602. https://doi.org/10.1086/519806

Maass JM, Balvanera P, Castillo A, Daily GC, Mooney HA, Ehrlich P, Quesada M, Miranda A, Jaramillo VJ, Garcia-Oliva F, Martinez-Yrizar A, Cotler H, Lopez-Blanco J, Perez-Jimenez A, Burquez A, Tinoco C, Ceballos G, Barraza $L$, Ayala R, Sarukhan J (2005) Ecosystem services of tropical dry forests: insights from longterm ecological and social research on the Pacific Coast of Mexico. Ecol Soc. https://doi.org/10.5751/ES-01219-100117

Mamo G, Sjaastad E, Vedeld P (2007) Economic dependence on forest resources: a case from Dendi District, Ethiopia. Forest Policy Econ 9(8):916-927. https://doi.org/10.1016/j.forpol.2006.08.001

McSweeney K (2002) Who is "forest-dependent"? capturing local variation in forest-product sale, Eastern Honduras. The Professional Geographer 54(2):158-174

McSweeney K, Jokisch B (2007) Beyond rainforests: Urbanisation and emigration among lowland indigenous societies in Latin America. Bull Latin Am Res 26:159-180. https://doi.org/10.1111/j.1470-9856.2007.00218.x

Mirza B, Szirmai A (2010) Towards a new measurement of energy poverty: A cross-community analysis of rural Pakistan. MERIT Working Papers 2010-024, United Nations University - Maastricht Economic and Social Research Institute on Innovation and Technology (MERIT)

Mukul SA, Rashid AZMM, Uddin MB, Khan NA (2016) Role of non-timber forest products in sustaining forest-based livelihoods and rural households 'resilience capacity in and around protected area: a Bangladesh study. J Environ Plan Manag 59:628-642. https://doi.org/10.1080/09640 568.2015.1035774
Neill JR (2006) Population and the natural environment: Trends and challenges. Popul Dev Rev 32(S1):183-201. https://doi.org/10.1111/j.1728-4457.2006. tb00007

Neumann RP, Hirsch E (2000) Commercialisation of non-timber forest products: review and analysis of research. In: Bogor, Indonesia: Center for International Forestry Research. Rome: FAO.

Nolte C, Agrawal A, Silvius KM, Soares-Filho BS (2013) Governance regime and location influence avoided deforestation success of protected areas in the Brazilian Amazon. Proc Natl Acad Sci 110(13):4956-4961. https://doi. org/10.1073/pnas.1214786110

Nune S, Kassie M, Mungatana E( 2013) Forest resource accounts in Ethiopia. In: Hassan RM, Mungatana ED (Eds) Implementing Environmental Accounts: Case Studies from Eastern and Southern Africa. Springer, Dordrecht, pp 103-142

Paumgarten $F$ (2005) The role of non-timber forest products as safety-nets: a review of evidence with a focus on South Africa. GeoJournal 64(3):189197. https://doi.org/10.1007/s10708-005-5647

Poverty Environment Network (PEN) (2007a) Poverty environment network prototype survey. http://www.cifor.org/pen/research-tools/the-penprototype-questionnaire.html.

Poverty Environment Network (PEN) (2007b) Poverty environment network technical guidelines version 4. http://www.cifor.org/pen/research-tools/ the-pen-technical-guidelines.html/

Pyhala A, Brown K, Adger WN (2006) Implications of livelihood dependence on non-timber products in Peruvian Amazonia. Ecosystems 9(8):1328-1341

Quang DV, Anh TN (2006) Commercial collection of NTFPs and households living in or near the forests: case study in Que, Con Cuong and $\mathrm{Ma}$, Tuong Duong, Nghe An. Vietnam Ecological Economics 60:65-74. https://doi. org/10.1016/j.ecolecon.2006.03.010

Rasul G, Karkri M, Sah RP (2008) The role of non-timber forest products in poverty reduction in India: prospects and problems. Dev Pract 18(6):779-788. https://doi.org/10.1080/09614520802386876

Reichhuber A, Requate T (2007) Alternative usesystems for the remaining cloud forest in Ethiopia and the role of Arabica coffee-a cost-benefit analysis, economics working paper, Christian-Albrechts-Universität Kiel: Department of Economics

Sasaki N, Putz FE (2009) Critical need for new definitions of forest and forest degradation in global climate change agreements. Conserv Lett 2:226-232. https://doi.org/10.1111/j.1755-263X.2009.0006

Sawyer S (2004) Crude chronicles: Indigenous politics, multinational oil, and neoliberalism in Ecuador. Duke University Press, Duke. https://doi. org/10.1215/9780822385752

Schroeder H, González NCP (2019) Bridging knowledge divides: the case of indigenous ontologies of territoriality and REDD + . For Policy Econ 2019(100):198-206

Shackleton C, Shackleton S (2004) The importance of non-timber forest products in rural livelihood security and as safety nets: a review of evidence from South Africa. S Afr J Sci 100(11):658-664

Shackleton CM, Guthrie G, Main R (2005) Estimating the potential role of commercial over-harvesting in resource viability: a case study of five useful tree species in South Africa. Land Degrad Dev 16:273-286

Sirén AH (2007) Population growth and land use intensification in a subsistence based indigenous community in the Amazon. Human Ecol 35(6):669-680. https://doi.org/10.1007/s10745-006-9089-y

Sunderlin W, Angelsen A, Belcher B, Burgers P, Nasi R, Santoso L et al (2005) Livelihoods, forests, and conservation in developing countries: an overview. World Dev 33(9):1383-1402. https://doi.org/10.1016/j.world dev.2004.10.004

Tadesse A, Bosona T, Gebresenbet G (2013) Rural Water Supply Management and Sustainability: The Case of Adama Area. Ethiopia. J Water Resour Prot 5(2):208-221. https://doi.org/10.4236/jwarp.2013.52022

Taye T (2009) The African Civet Cat (Viverra civetta) and its life supporting role in the livelihood of smallholder farmers in Ethiopia. In: Paper presented at a conference on international research on food security, natural resource management and rural development, University of Hamburg (available here).

Thabbie C (2014) Livelihood strategies and forest reliance in Malawi. Forests Trees Livelihoods 23(3):188-210. https://doi.org/10.1080/14728 028.2014 .922449

Teketay DF, Senbeta M, Maclachlan M, Bekele P (2010) Edible Wild Plants in Ethiopia. Addis Ababa University Press, Addis Ababa, Ethiopia 
Timko J, Waeber P, Kozak R (2010) The socio-economic contribution ofnon-timber forest products to rural livelihoods in Sub-Saharan Africa:knowledge gaps and new directions. Int For Rev 12:284-294. https://doi.org/10.1505/ ifor.12.3.284

Vedeld P, Angelsen A, Sjaastad E, Kobugabe BG (2004) Counting on the Environment: Forest Incomes and the Rural Poor. Environment Economics Series Paper 98. World Bank, Washington D.C.

Vedeld P, Angelsen A, Bojo J, Sjaastad E, Berg KG (2007) Forest environmental incomes and the rural poor. For Policy Econ 9(7):869-879. https://doi. org/10.1016/j.forpol.2006.05.008

Wen Y, Theint Htun T, Chan Ko Ko A (2017) Assessment of forest resources dependency for local livelihood around protected area: a case study in Popa mountain park Central Myanmar. Internet J Sci 3:34. https://doi. org/10.18483/ijSci.1176
World Bank (2002) A revised forest strategy for the World Bank Group. The World Bank, Washington

Yimer T ( 2016) Assessment of the Socio-economic Value of Forest Products for Rural Communities in Ethiopia - Final Report. Ministry of Environment, Forestry and Climate Change, Addis Ababa

Yuan JW, Wu QX, Liu JL (2012) Understanding indigenous knowledge in sustainable management of natural resources in China taking two villages from Guizhou Province as a case. For Policy Econ 2012(22):47-52. https:// doi.org/10.1016/j.forpol.2012.02.012

\section{Publisher's Note}

Springer Nature remains neutral with regard to jurisdictional claims in published maps and institutional affiliations.

\section{Submit your manuscript to a SpringerOpen ${ }^{\odot}$ journal and benefit from:}

- Convenient online submission

- Rigorous peer review

- Open access: articles freely available online

- High visibility within the field

- Retaining the copyright to your article

Submit your next manuscript at $\boldsymbol{\nabla}$ springeropen.com 